\title{
Genital tract morphometry and haematology of male rabbits fed graded levels of cassava leaf meal
}

\author{
Ahemen $^{1 *}$, T., Bitto ${ }^{1}$, I.I., Oluremi², O.I.A. and Anugwa ${ }^{2}$, F.O.I. \\ ${ }^{1}$ Department of Animal Breeding and Physiology University of Agriculture Makurdi \\ ${ }^{2}$ Department of Animal Nutrition University of Agriculture Makurdi \\ *Corresponding Author: memberter@yahoo.com
}

\begin{abstract}
A study was conducted to investigate the effects offeeding graded levels of cassava leaf meal (CLM) on genital tract morphometry and haematology of twenty 8-week old male rabbits weighing between 815 to $910 \mathrm{~g}$. The rabbits were randomly assigned to four dietary treatments viz: $T_{1}$ (control), $T_{2}, T_{3}$ and $T_{4}$ with CLM inclusion levels of $0 \%, 9 \%, 18 \%$, and $27 \%$, respectively after balancing for liveweight. Each rabbit was individually caged and served as a replicate in a completely randomized design. The feeding trial lasted for sixteen (16) weeks. Three (3) rabbits per treatment were slaughtered and evaluated for genital tract morphometry and haematological characteristics. The results showed that CLM had no significant effect $(P>0.05)$ on testes, corpus, cauda, ductus and tunic weights. Positive relationships were observed between CLM in the diets and testes weight $(r=0.42 ; P<0.05)$ as well as cauda weights $(r=0.96 ; P<0.01)$. No significant effect $(P>0.05)$ of diets were observed on packed cell volume, haemoglobin, mean corpuscular haemoglobin, mean corpuscular haemoglobin concentration, mean corpuscular volume, platelets, white blood cells, neutrophils, lymphocytes, monocytes basophils and eosinophils. However negative relationships between levels of inclusion of CLM in diets and red blood cell, packed cell volume and haemoglobin were observed. It was concluded that the inclusion of up to $27 \%$ of CLM in bucks' diets is not detrimental to good health and normal reproductive tract development. It is recommended that further studies on the feeding potentials of cassava leaf meal at higher levels of inclusion and actual reproductive performance be investigated.
\end{abstract}

Keywords: Cassava leaf, rabbit, dietary treatments, reproductive tract, morphometry, haematological characteristics

\section{Introduction}

Rabbit production has enormous potential in alleviating the problems of animal protein supply in a developing economy like Nigeria (Ajayi et al., 2007). The importance of rabbit in Nigeria as a source of animal protein has been reported (Amaefule et al., 2004). Some of the characteristics favouring rabbit production include: small body size, short generation interval and high reproductive rates, rapid growth and the ability to utilize forage and fibrous agricultural by-products (Cheeke,
1986). Thus, attention is now being shifted to rabbit production in order to solve the problem of animal protein shortage in Nigeria. The use of forage and agricultural by-products has become an area of interest to many researchers because of the challenges posed by the high cost of conventional feedstuffs. Cassava leaves are readily available as a by-product at the time of harvesting the roots. Various studies have been conducted to determine the chemical composition and feeding value of cassava leaf meal (CLM) in rabbits (Fumunyam and 
Meffega, 1987; Agunbiade, et al., 1999; Adegbola and Okonkwo, 2002). Adegbola and Okonkwo (2002) reported a crude protein value of $24.2 \%$, crude fibre content of $14.87 \%$ and gross energy of 19.66 $\mathrm{MJ} / \mathrm{Kg}$. Phuc et al. (2006) reported 33.3\% crude protein, $24.4 \% \mathrm{NDF}, 7.2 \%$ ether extract, and $21.4 \mathrm{MJ} / \mathrm{Kg}$ on dry matter basis. A major factor limiting the use of fresh cassava leaves is its cyanide content. Hydrogen cyanide has been shown to be toxic to livestock (Tewe, 1992), and therefore limits its use in the raw state as feed for livestock (Smith, 1988). Detoxification of cassava leaves has been made possible through sun drying (Tewe et al., 1979; Ravindran, et al., 1987).

Haematological components of blood are valuable in monitoring feed toxicity especially with feed constituents that affect the formation of blood (Oyawoye and Ogunkunle, 1998). A number of factors affect reproductive parameters and fertility in rabbits. Such factors include age, nutrition, environment, health status or disease, frequency of use, and management. While, Bitto et al. (2006) reported the effects of pawpaw peel meal on reproductive tract morphometry and some haematological characteristics of female rabbits, Oyeyemi and Okediran (2007) studied the testicular parameters and sperm morphology of male rabbits fed with different planes of soybean meal. Although sun-dried cassava leaf meal had been safely incorporated into rations of rabbits without negative effect on growth performance, not much has been reported on the effect of cassava leaf meal on the reproductive and haematological parameters of rabbits.

This study was designed to investigate the effect of cassava leaf meal on morphometry of the reproductive tract sections and haematology of male rabbits.

\section{Materials and Methods}

\section{Location}

The study was conducted at the Rabbitary unit of the Livestock Research Farm, University of Agriculture, Makurdi, Nigeria. Makurdi is located at Latitude $7^{\circ}$ 14' North and Longitude $8^{\circ} 21^{\prime}$ East and lies within the Southern guinea savannah region of Nigeria. The area is warm with temperature range of 24.20 to $36.33^{\circ} \mathrm{C}$ and high temperature is experienced between late February and April. The rainfall is between 508 and 1016mm (TAC, 2009).

Source of Cassava leaves and preparation of experimental diets

The test ingredient, cassava leaves (bitter variety) were obtained from the local farms in and around Makurdi after cassava roots had been harvested. The leaves were sundried single layered on a concrete platform or 3-4 days to attained less than $10 \%$ moisture. The leaves were thereafter milled using hammer mill to obtain the cassava leaf meal (CLM) which was then mixed with other ingredients to produce the experimental diets. The sun-dried cassava leaves were included at the levels of $0,9,18$ and $27 \%$ in diets $\mathrm{T}_{1}, \mathrm{~T}_{2}, \mathrm{~T}_{3}$ and $\mathrm{T}_{4}$, respectively. Other ingredients used were maize, full fat soya beans, brewers dried grain, rice offal, and bone meal and vitamin premix (Table 1).

Experimental animals and management

Twenty 8-week old healthy weaner male rabbits of mixed breeds (California, New Zealand, American Chinchilla and Dutch) were used for the experiment. The rabbits weighed 815-910g and were allowed a preliminary period of two-weeks before the feeding trial commenced. During this 
Ahemen, Bitto, Oluremi and Anugwa

Table 1: Ingredient and nutrient composition (\%) of the experimental diets

\begin{tabular}{|c|c|c|c|c|}
\hline \multirow{2}{*}{ Ingredients } & \multicolumn{4}{|c|}{ Experimental diets } \\
\hline & $\mathrm{T}_{1}$ & $\mathrm{~T}_{2}$ & $\mathrm{~T}_{3}$ & $\mathrm{~T}_{4}$ \\
\hline Maize & 48.21 & 43.00 & 38.43 & 33.11 \\
\hline Full fat soybean meal & 23.74 & 19.95 & 15.52 & 11.84 \\
\hline Cassava leaf meal & 0.00 & 9.00 & 18.00 & 27.00 \\
\hline Brewers dried grain & 10.00 & 10.00 & 10.00 & 10.00 \\
\hline Rice offal & 15.00 & 15.00 & 15.00 & 15.00 \\
\hline Bone meal & 2.50 & 2.50 & 2.50 & 2.50 \\
\hline Mineral-vitamin premix* & 0.25 & 0.25 & 0.25 & 0.25 \\
\hline Common salt & 0.30 & 0.30 & 0.30 & 0.30 \\
\hline Maize & 48.21 & 43.00 & 38.43 & 33.11 \\
\hline Total & 100.00 & 100.00 & 100.00 & 100.00 \\
\hline \multicolumn{5}{|l|}{ Calculated values } \\
\hline Crude protein $(\%)$ & 17.00 & 17.00 & 17.02 & 17.15 \\
\hline Crude fibre $(\%)$ & 8.61 & 9.72 & 10.82 & 11.92 \\
\hline $\mathrm{DE}(\mathrm{Kcal} / \mathrm{kg})$ & 3074.04 & 2994.23 & 2915.32 & 2835.36 \\
\hline \multicolumn{5}{|c|}{ 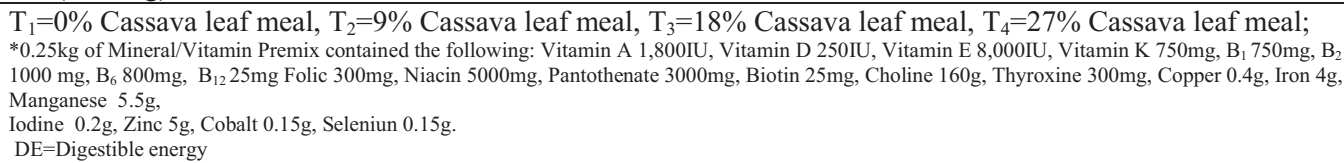 } \\
\hline
\end{tabular}

period they were fed a common diet. The rabbits were treated with ivermectin subcutaneously at a dosage of $0.1 \mathrm{ml}$ per rabbit against ecto and endo-parasites. After the adjustment period, the animals were weighed, divided into four (4) groups of five (5) rabbits each, and each rabbit served as a replicate. The rabbits were managed intensively and housed individually in hutches. The experimental diets and clean drinking water were supplied to the rabbits ad libitum throughout the feeding period which lasted for sixteen (16) weeks.

\section{Genital tractmorphometry}

At the end of the sixteen (16) weeks of feeding trial, 3 bucks were randomly selected from each experimental diet. The bucks were starved for 12 hours and thereafter sacrificed by stunning and decapitation. The male reproductive tract was carefully removed and weighed.
Similarly, the various components of the reproductive tract namely, tunic, testis, caput, corpus, cauda and ductus deferens were separated, trimmed free of fats and weighed using highly sensitive digital balance.

\section{Haematology assay}

Two (2) $\mathrm{ml}$ blood samples were collected from the sacrificed bucks at slaughter from the jugular vein at the neck region into ethylene diamine tetra acetic acid (EDTA) treated bottles and were analysed using Sysmex X21K; an automatic counter. This analyzer works on the principles of aperture impedance. The blood was highly diluted in buffered electrolyte solution and a measure of it was made to flow through an aperture tube of specific dimension. A direct current was maintained between an electrode in the sample beaker by a constant source of electricity as reported by Ahemen (2012). As blood cells pass through the orifice of 
the aperture tube, it displaces some of the conductive fluid and increases the electrical resistance thus producing a corresponding change in potential between the electrode which last as long as the cell passes through the aperture and assume the shape of a pulse having amplitude proportional to the cell volume. The haematological indices evaluated were haemoglobin $(\mathrm{Hb})$ concentration, packed cell volume (PCV), red blood cell (RBC) counts, white blood cell (WBC) counts and leucocyte differential counts mean corpuscular haemoglobin $(\mathrm{MCH})$, Mean corpuscular volume (MCV), mean corpuscular haemoglobin concentration (MCHC) and platelets as reported by Bitto and Gemade (2001).

Statistical Analysis

Data obtained were subjected to analyses of variance and correlation using GenStat (Release 4.24) statistical package (Genstat, 2005). Significant differences between treatment means were separated using Duncan's Multiple Range Test of the same statistical package.

\section{Results and Discussion}

The results of genital tract morphometry of male rabbits fed graded levels of cassava leaf meal are presented in Tables 2, 3 and 4. There was no significant $(\mathrm{P}>0.05)$ effect of diets on the testicular parameters and their derivations from body weight except paired caput weight in Tables 2 and 3. Values showed fluctuating trend. This result shows that the incorporation of CLM in the diet of rabbit up to $27 \%$ may not affect reproductive organs growth and consequently fertility of male rabbits. The result is similar to the report of Bitto and Gemade (2001) who observed nonsignificant effect of pawpaw peel meal on reproductive morphometry of male rabbits. It also agrees with the report of Ogunlade $e t$ al. (2006) who observed non-significant differences in testis weight among rabbits fed fumonisins contaminated diets and those on control, and concluded that testes weight appeared to be stable regardless of treatment. However, the result in this study contrast with the report of Bitto et al. (2000) who observed a significant depression in paired testes weight of cockerels fed cassava peel meal up to $30 \%$ in diet. Egbunike (1979) observed testicular degeneration and impaired spermatogenesis on rats treated with sublethal dose of aflatoxin Torhemen (2008) reported significant effect of diet on testes weights of rabbits fed up to $75 \%$ cassava peel meal with testes weights increasing with increased levels of inclusion of cassava leaf meal in diets.

Positive relationships between levels of inclusion of CLM and testicular weight $(\mathrm{r}=0.414 ; \mathrm{P}>0.05)$ as well as cauda weight $(\mathrm{r}=0.96 ; \mathrm{P}<0.01)$ were observed in Table 4. The Positive correlations found between levels of inclusion of CLM and testes weight as well as paired cauda weight point to the fact that CLM will support normal testicular development in rabbits when incorporated up to 27 per cent in the diet of male rabbits and there is tendency for improved testicular growth when incorporated at higher levels. These indicate that inclusion of CLM in the diet of male rabbits is beneficial to the development of spermatogenic potentials 
Table 2: Morphometric characteristics of the reproductive organs of male rabbits fed varying dietary levels of cassava leaf meal (mean \pm SEM)

\begin{tabular}{|c|c|c|c|c|}
\hline \multirow[b]{2}{*}{ Parameters } & \multicolumn{3}{|c|}{ Experimental Diets } & \multirow[b]{2}{*}{$\mathrm{T}_{4}$} \\
\hline & $\mathrm{T}_{1}$ & $\mathrm{~T}_{2}$ & $\mathrm{~T}_{3}$ & \\
\hline Body weight (g) & $1717.7 \pm 220.48$ & $1850.00 \pm 300$ & $1950.00 \pm 175.59$ & $1816.7 \pm 185.59$ \\
\hline Scrotal circumference $(\mathrm{cm})$ & $13.33 \pm 1.58$ & $12.27 \pm 1.73$ & $12.87 \pm 1.23$ & $11.87 \pm 0.77$ \\
\hline Left tunic weight $(\mathrm{g})$ & $0.17 \pm 0.03$ & $0.27 \pm 0.03$ & $0.23 \pm 0.03$ & $0.20 \pm 0.00$ \\
\hline Right tunic weight (g) & $0.20 \pm 0.00$ & $0.27 \pm 0.23$ & $0.20 \pm 0.00$ & $0.30 \pm 0.12$ \\
\hline Paired tunic weight (g) & $0.37 \pm 0.03$ & $0.53 \pm 0.07$ & $0.43 \pm 0.03$ & $0.50 \pm 0.12$ \\
\hline Left testes weight (g) & $1.63 \pm 0.42$ & $1.53 \pm 0.34$ & $1.90 \pm 0.10$ & $1.60 \pm 0.15$ \\
\hline Right testis weight (g) & $1.43 \pm 0.37$ & $1.47 \pm 0.29$ & $1.93 \pm 0.19$ & $1.50 \pm 0.23$ \\
\hline Paired testis weight (g) & $3.06 \pm 0.78$ & $3.00 \pm 0.62$ & $3.83 \pm 0.29$ & $3.10 \pm 0.38$ \\
\hline Left caput weight (g) & $0.30 \pm 0.06$ & $0.40 \pm 0.00$ & $0.40 \pm 0.06$ & $0.43 \pm 0.03$ \\
\hline Right caput weight (g) & $0.27 \pm 0.03$ & $0.40 \pm 0.06$ & $0.47 \pm 0.03$ & $0.33 \pm 0.33$ \\
\hline Paired caput weight (g) & $0.57 \pm 0.09^{b}$ & $0.80 \pm 0.05^{\mathrm{a}}$ & $0.87 \pm 0.03^{\mathrm{a}}$ & $0.77 \pm 0.09^{\mathrm{a}}$ \\
\hline Left corpus weight (g) & $0.27 \pm 0.03$ & $0.27 \pm 0.09$ & $0.33 \pm 0.03$ & $0.30 \pm 0.06$ \\
\hline Right corpus weight (g) & $0.40 \pm 0.10$ & $0.37 \pm 0.07$ & $0.33 \pm 0.03$ & $0.33 \pm 0.03$ \\
\hline Paired corpus weight $(\mathrm{g})$ & $0.67 \pm 0.12$ & $0.63 \pm 0.15$ & $0.67 \pm 0.03$ & $0.63 \pm 0.09$ \\
\hline Left cauda weight (g) & $0.13 \pm 0.03$ & $0.20 \pm 0.06$ & $0.17 \pm 0.03$ & $0.27 \pm 0.07$ \\
\hline Right cauda weight (g) & $0.20 \pm 0.00$ & $0.23 \pm 0.09$ & $0.30 \pm 0.06$ & $0.23 \pm 0.03$ \\
\hline Paired cauda weight (g) & $0.33 \pm 0.03$ & $0.43 \pm 0.15$ & $0.47 \pm 0.09$ & $0.50 \pm 0.06$ \\
\hline Right ductus weight (g) & $0.13 \pm 0.03$ & $0.27 \pm 0.03$ & $0.17 \pm 0.03$ & $0.20 \pm 0.00$ \\
\hline Left ductus weight (g) & $0.23 \pm 0.03$ & $0.23 \pm 0.03$ & $0.23 \pm 0.03$ & $0.23 \pm 0.03$ \\
\hline Paired ductus weight (g) & $0.37 \pm 0.03$ & $0.50 \pm 0.06$ & $0.40 \pm 0.00$ & $0.43 \pm 0.03$ \\
\hline
\end{tabular}

$\mathrm{SEM}=$ Standard error of mean; $\mathrm{T}_{1}=0 \%$ Cassava leaf meal, $\mathrm{T}_{2}=9 \%$ Cassava leaf meal, $\mathrm{T}_{3}=18 \%$ Cassava leaf meal, $\mathrm{T}_{4}=27 \%$ Cassava leaf meal

${ }^{\mathrm{a}, \mathrm{b}}$ Means in the same row with different superscripts are significantly different $(\mathrm{P}<0.05)$;

Table 3: Derivations from genital tract morphometry based on body weight of male rabbits fed varying dietary levels of cassava leaf meal (mean \pm SEM)

\begin{tabular}{lcccc}
\multicolumn{5}{c}{ rabbits fed varying dietary levels of cassava leaf meal (mean \pm SEM) } \\
\cline { 2 - 5 } Parameters & $\mathrm{T}_{1}$ & Experimental & Diets & $\mathrm{T}_{4}$ \\
\hline Left tunic & $0.01 \pm 0.00$ & $0.01 \pm 0.00$ & $0.01 \pm 0.00$ & $0.20 \pm 0.00$ \\
Right tunic & $0.01 \pm 0.00$ & $0.01 \pm 0.00$ & $0.01 \pm 0.00$ & $0.01 \pm 0.00$ \\
Paired tunic & $0.02 \pm 0.00$ & $0.03 \pm 0.00$ & $0.02 \pm 0.00$ & $0.03 \pm 0.01$ \\
Left testis & $0.09 \pm 0.02$ & $0.08 \pm 0.03$ & $0.11 \pm 0.01$ & $0.09 \pm 0.00$ \\
Right testis & $0.08 \pm 0.02$ & $0.07 \pm 0.03$ & $0.11 \pm 0.01$ & $0.08 \pm 0.00$ \\
Paired testes & $0.17 \pm 0.03$ & $0.19 \pm 0.04$ & $0.22 \pm 0.01$ & $0.17 \pm 0.01$ \\
Left caput & $0.02 \pm 0.00$ & $0.02 \pm 0.00$ & $0.03 \pm 0.00$ & $0.03 \pm 0.00$ \\
Right caput & $0.02 \pm 0.00$ & $0.01 \pm 0.01$ & $0.02 \pm 0.00$ & $0.02 \pm 0.00$ \\
Paired caput & $0.04 \pm 0.00^{\mathrm{ab}}$ & $0.03 \pm 0.01^{\mathrm{b}}$ & $0.05 \pm 0.00^{\mathrm{a}}$ & $0.05 \pm 0.13^{\mathrm{a}}$ \\
Left corpus & $0.02 \pm 0.00$ & $0.02 \pm 0.01$ & $0.02 \pm 0.00$ & $0.02 \pm 0.00$ \\
Right corpus & $0.02 \pm 0.00$ & $0.02 \pm 0.01$ & $0.02 \pm 0.00$ & $0.02 \pm 0.00$ \\
Paired corpus & $0.04 \pm 0.00$ & $0.04 \pm 0.00$ & $0.05 \pm 0.00$ & $0.05 \pm 0.01$ \\
Left cauda & $0.01 \pm 0.00$ & $0.01 \pm 0.01$ & $0.01 \pm 0.00$ & $0.01 \pm 0.00$ \\
Right cauda & $0.01 \pm 0.00$ & $0.01 \pm 0.01$ & $0.02 \pm 0.01$ & $0.01 \pm 0.00$ \\
Paired cauda & $0.02 \pm 0.00$ & $0.02 \pm 0.00$ & $0.03 \pm 0.00$ & $0.02 \pm 0.00$ \\
Left ductus & $0.01 \pm 0.00$ & $0.01 \pm 0.00$ & $0.01 \pm 0.00$ & $0.01 \pm 0.00$ \\
Right ductus & $0.01 \pm 0.01$ & $0.01 \pm 0.00$ & $0.01 \pm 0.00$ & $0.01 \pm 0.00$ \\
Paired ductus & $0.02 \pm 0.00$ & $0.03 \pm 0.00$ & $0.02 \pm 0.00$ & $0.02 \pm 0.00$ \\
\hline SEM=Standard error of mean; $\mathrm{T}_{1}=0 \%$ Cassava leaf meal, $\mathrm{T}_{2}=9 \%$ Cassava leaf meal, $\mathrm{T}_{3}=18 \%$ Cassava \\
leaf meal, \\
$\mathrm{T}_{4}=27 \%$ Cassava leaf meal & & & \\
a,b Means in the same row with different superscripts are significantly different $(\mathrm{P}<0.05) ;$
\end{tabular}


Genital tract morphometry of male rabbits fed graded levels of cassava leaf meal

Table 4: Correlation matrix of cassava leaf meal in diets with testicular morphometry

\begin{tabular}{lllllll}
\hline & ALE & CAPT & CAUD & CORPS & DUCTS & TESTS \\
\hline ALE & 1.000 & & & & & \\
CAPT & 0.460 & 1.000 & & & & \\
CAUD & $0.958^{* *}$ & $0.655^{* *}$ & 1.000 & & & \\
CORPS & $-0.447^{*}$ & 0.000 & $0.506^{*}$ & 1.000 & & \\
DUCTS & 0.185 & 0.338 & $0.392^{*}$ & $-0.830^{* *}$ & 1.000 & \\
TESTS & $0.414^{*}$ & $0.756^{* *}$ & 0.365 & $0.584^{*}$ & -0.361 & 1.000 \\
\hline
\end{tabular}

$\mathrm{ALE}=$ levels of inclusion of cassava leaves, $\mathrm{CAPT}=$ Caput, $\mathrm{CAUD}=$ cauda, $\mathrm{CORPS}=\mathrm{Corpus}$, DUCTS $=$ Ductus deferens, TESTS $=$ Testes

$* *$ Correlation is significant at $1 \%(\mathrm{P}<0.01),{ }^{*}$ Correlation is significant at $5 \%(\mathrm{P}<0.05)$.

of the buck. Testicular weight is a good indicator of sperm production of an animal (Morris et al. 1979; Bitto and Gemade, 2001; Ahemen et al. 2011). The knowledge of basic morphometric characteristics of the reproductive organs has been found to provide valuable information in the evaluation of breeding and fertility potential of the animals (Orji, 1985). Gage and Freckleton (2003) described the mammalian testes size and weight as infallible predictors of spermatozoa production, and further asserted that knowledge of the basic morphometric characteristics of the reproductive organs is mandatory for assessment and prediction not only of sperm production but also of the storage potential and fertilizing ability of the breeder male.

The results of the effect of cassava leaf meal on the haematological values of male rabbits are shown in Tables 5 and 6 . The packed cell volume (PCV), haemoglobin $(\mathrm{Hb})$, mean corpuscular haemoglobin $(\mathrm{MCH})$, mean corpuscular haemoglobin concentration (MCHC) mean corpuscular volume (MCV), platelets, red blood cell $(\mathrm{RBC})$ counts were not significantly $(\mathrm{P}>0.05)$ different between treatments. The non-significant effect of diet on values of red blood cells (RBC), packed cell volume $(\mathrm{PCV})$ and haemoglobin $(\mathrm{Hb})$ is an indication that the animals were not anaemic. It also implies that the dietary proteins were of good quality (Abu et al., 1998). The values of white blood cells were within normal range $\left(5-8 \times 10^{3} / \mathrm{mm}^{3}\right)$ for healthy rabbits (Mitruka and Rawnsley, 1977) except in bucks on $T_{2}$ with value lower than the reference range. White blood cell count below the normal range is an indication of allergic conditions, anaphylactic shock and certain parasitism, while elevated values indicate the existence of recent infection, usually with bacteria (Ahamefule, et al., 2008). In the present study, the low WBC value observed in $\mathrm{T}_{2}$ does not show the influence of diets since the low values were not observed from treatments with higher levels of the test ingredient. This is an indication that the diets have no negative effect on WBC counts. The non-significant $(\mathrm{P}>0.05)$ effect of CLM-based diet on white blood cell (WBC) and leucocyte differential counts; neutrophils, lymphocytes, monocytes, basophils and eosinophils show the effectiveness of sun-drying in detoxifying cassava leaves. The lymphocyte count of rabbits in $\mathrm{T}_{3}$ was slightly above the normal 
Table 5: Haematological indices of male rabbits fed varying dietary levels of cassava leaf meal (mean \pm SEM)

\begin{tabular}{lccccc}
\hline & \multicolumn{5}{c}{ Experimental Diets } \\
\cline { 2 - 5 } Parameters & $\mathrm{T}_{1}$ & $\mathrm{~T}_{2}$ & $\mathrm{~T}_{3}$ & $\mathrm{~T}_{4}$ & LOS \\
\hline Packed Cell Volume (\%) & $57.27 \pm 11.82$ & $50.35 \pm 2.96$ & $52.13 \pm 12.79$ & $47.27 \pm 3.70$ & $\mathrm{~ns}$ \\
Heamoglobin (g/dl) & $20.10 \pm 3.58$ & $15.10 \pm 2.14$ & $17.47 \pm 4.23$ & $15.77 \pm 1.25$ & $\mathrm{~ns}$ \\
MCH (pg) & $25.87 \pm 0.71$ & $43.90 \pm 17.17$ & $26.00 \pm 1.42$ & $17.30 \pm 8.20$ & $\mathrm{~ns}$ \\
MCHC (g/dl) & $0.37 \pm 0.33$ & $0.40 \pm 0.00$ & $0.33 \pm 0.03$ & $0.63 \pm 2.80$ & $\mathrm{~ns}$ \\
MCV (fl) & $81.6 \pm 2.00$ & $81.2 \pm 1.60$ & $77.20 \pm 3.90$ & $76.90 \pm 0.70$ & $\mathrm{~ns}$ \\
Platelets (x109) & $634.0 \pm 142.80$ & $259.7 \pm 95.60$ & $370.00 \pm 68.70$ & $56.0 \pm 62.60$ & $\mathrm{~ns}$ \\
Red blood cells (x10 $\left.{ }^{12} / \mathrm{L}\right)$ & $6.96 \pm 1.26$ & $5.82 \pm 0.60$ & $5.37 \pm 1.04$ & $5.90 \pm 1.65$ & $\mathrm{~ns}$ \\
White blood cells $\left(\mathrm{x} 10^{9} / \mathrm{L}\right)$ & $5.53 \pm 1.21$ & $3.63 \pm 0.41$ & $5.37 \pm 1.04$ & $5.90 \pm 1.65$ & $\mathrm{~ns}$ \\
Leucocyte differentials $(\%)$ & & & & \\
Neutrophils & $35.60 \pm 2.00$ & $38.67 \pm 0.58$ & $26.33 \pm 8.12$ & $36.00 \pm 0.58$ & $\mathrm{~ns}$ \\
Esinophils & $2.67 \pm 0.88$ & $2.00 \pm 0.57$ & $2.00 \pm 0$ & $2.33 \pm 0.33$ & $\mathrm{~ns}$ \\
Lymphocytes & $56.33 \pm 1.45$ & $58.47 \pm 0.30$ & $69.67 \pm 8.67$ & $60.67 \pm 0.67$ & $\mathrm{~ns}$ \\
Monocytes & $1.33 \pm 0.30$ & $1.00 \pm 0.58$ & $1.33 \pm 0.33$ & $0.50 \pm 0.00$ & $\mathrm{~ns}$ \\
Basophils & $0.67 \pm 0.67$ & $0 \pm 0.00$ & $0.67 \pm 0.33$ & $0.33 \pm 0.33$ & $\mathrm{~ns}$ \\
\hline LOS = Level of significance, ns = not significant $(\mathrm{P}>0.05) ;$ sem=Standard error of mean; $\mathrm{T}_{1}=0 \%$ Cassava leaf meal, $\mathrm{T}_{2}=9 \%$ Cassava leaf meal, \\
$\mathrm{T}_{3}=18 \%$ Cassava leaf meal, $\mathrm{T}_{4}=27 \%$ Cassava leaf meal; $\mathrm{MCH}=$ mean corpuscular haemoglobin, MCHC= mean corpuscular haemoglobin \\
concentration, MCV= mean corpuscular volume. & & & &
\end{tabular}

range (53.5 - 65.8\%) recommended by Kronfield and Mediway (1979) and the range of $28-50 \%$ recommended by Mitruka and Rawnsley (1977) for a healthy rabbit. It is probable that the raised lymphocyte count could be an indication that the rabbits were immunologically challenged by the anti-nutritional factors residues in cassava leafmeal.

Negative significant relationship existed between levels of inclusion of CLM and $\mathrm{Hb}$ $(\mathrm{r}=-0.62 ; \mathrm{P}<0.05), \mathrm{PCV}(\mathrm{r}=-0.87$; $\mathrm{P}<0.01)$, $\mathrm{RBC}(\mathrm{r}=-0.70 ; \mathrm{P}<0.01)$ as well as platelets $(\mathrm{r}=-0.58 ; \mathrm{P}<0.05)$ in Table 6 . The negative associations between levels of inclusion of CLM in diets and RBC, PCV, as well as $\mathrm{Hb}$ show that there is tendency for decrease red blood cells production with increase inclusion levels of cassava leaf meal in the diet of rabbits. The negative correlations may be due to the activity of traces of anti-nutritional factors. Ravindran et al. (1987) reported that sun-drying processing technique reduces only $90 \%$ of the total cyanide content in cassava leaves. Positive relationship $(\mathrm{r}=0.53 ; \mathrm{P}<0.05)$ was observed between levels of inclusion of CLM and lymphocyte count. The positive correlation observed could be a physiological adjustment presented by the animals against negative antigenic effect associated with residual anti-nutritional factors in CLM.

\section{Conclusion}

It was concluded that the inclusion of cassava leaf meal up to $27 \%$ in buck diet has no deleterious effect on haematological indices and would support normal reproductive tract development. Further studies on the feeding potentials of cassava leaf meal at higher levels of inclusion should be investigated in view of the negative relationships between levels of inclusion of cassava leaf meal and some 
Genital tract morphometry of male rabbits fed graded levels of cassava leaf meal

Table 6: Correlation matrix of cassava leaf meal in diets with haematology of male rabbits

\begin{tabular}{|c|c|c|c|c|c|c|c|c|c|c|}
\hline & ALE & $\mathrm{B}$ & $\mathrm{E}$ & $\mathrm{Hb}$ & $\mathrm{L}$ & $\mathrm{M}$ & $\mathrm{N}$ & PCV & $\mathrm{RBC}$ & WBC \\
\hline ALE & 1.00 & & & & & & & & & \\
\hline B & 0.14 & 1.00 & & & & & & & & \\
\hline E & $-0.41 *$ & 0.46 & 1.00 & & & & & & & \\
\hline $\mathrm{Hb}$ & $-0.62 * *$ & $0.84 * *$ & $0.73 * *$ & 1.00 & & & & & & \\
\hline $\mathrm{L}$ & 0.53 & 0.37 & $-0.63 * *$ & -0.14 & 1.00 & & & & & \\
\hline M & $-0.71 * *$ & $0.56^{*}$ & 0.04 & $0.68 * *$ & 0.21 & 1.00 & & & & \\
\hline $\mathrm{N}$ & -0.27 & $-0.70 * *$ & 0.31 & -0.28 & $-0.91 * *$ & $-0.48 *$ & 1.00 & & & \\
\hline PCV & $-0.87 * *$ & $0.61 * *$ & $0.55^{*}$ & $0.91 * *$ & -0.24 & $0.85^{* *}$ & -0.14 & 1.00 & & \\
\hline $\mathrm{RBC}$ & $-0.70 * *$ & 0.26 & $0.92 * *$ & $0.70 * *$ & $-0.80 * *$ & 0.20 & $0.490^{*}$ & $0.68 * *$ & 1.00 & \\
\hline WBC & 0.36 & $0.74 * *$ & $0.56^{*}$ & $0.48^{*}$ & 0.21 & -0.14 & $-0.41 *$ & 0.08 & 0.21 & 1.00 \\
\hline
\end{tabular}

haematological indices, and, positive relationships between levels of inclusion of cassava leaf meal and some reproductive tract parameters.

\section{Acknowledgements}

We wish to acknowledge Dr. Zahraddeen, D., Department of Animal Science, Ahmadu Bello University Zaria- Nigeria for his assistance.

\section{References}

Abu, O.A., Rabo, J.S., Onifade, A.A. and Danny, C. B. 1998. B lood composition and histological changes in the gastro-intestinal tract of rabbit fed untreated rice husk based diets. Proc. Silver Anniversary Conf. Nig. Soc. Anim. Prod. held at Abeokuta, Nigeria (1998). Ed (s) O.O. Oduguwa, O.A. Fanimo and O.A. Osinowo. 23:144-147.

Adegbola, T.A. and Okonkwo, J. C. 2002. Nutrient intake digestibility and growth of rabbits fed varying levels of cassava leaf meal. Nigerian Journal of Animal Production. 29: 21 68.

Agunbiade, J.A., Adeyemi, O.A., Fasina, O.E., Ashorobi, B.O., Adebanlo O. and Wade, O.A. 1999. Cassava peels and leaves in the diet of rabbits. Effects on performance and carcass characteristics. Nig. J. Anim. Prod., 26:29-34.

Ahamefule, F. O., Obua, B.E., Ukweni, I.A., Oguike, M.A. and Amaka, R.A. 2008. Haematological and biochemical profile of weaner rabbits fed raw or processed $\mathrm{p}$ i $\mathrm{g}$ e $\mathrm{o} \mathrm{n}$ pea seed meal based diets. African Journal of Agricultural Research 3(4) :315-319.

Ahemen, T. 2012. The effect of cassava leaf meal on growth and reproductive performance of rabbits in a southern guinea savannah environment. Ph.D. Thesis Department of Animal Breeding and Physiology, University ofAgriculture, Makurdi, Nigeria. Pp. 87-89.

Ahemen, T., Bitto, I.I. and Anugwa, F.O.I. 2011. Sperm production rate, gonadal and extragonadal sperm reserves of West African dwarf rams in the Southern guinea Savanna of Nigeria. Nigerian Journal of Animal Science 13:29-35.

Ajayi, A. F., Farinu, G.O., Ojebiyi, O.O. and Olayeni, T.B. 2007. Performance evaluation of male rabbits fed diets containing graded levels of blood-wild sunflower leaf meal mixture. World Journal of Agricultural Science 3 (2): 250-255. 
Amaefule, K.U., Nwaokoro, C.C. and Iheukwumere, F.C. 2004. Effects of graded levels of raw pigeon pea seed (Cajanus cajan) meal on the performance, nutrient retention and carcass characteristics of weaner rabbits. Nigerian Journal of Animal Production 31: 194-199.

Bitto, I.I., Sende, C.T. and Eze, P.U. 2000. Preliminary investigations on the effect of cassava peel meal on testicular morphometry and some biochemical characteristics of serum in cockerels. Global Journal of Pure and Applied Science 6(2): 161-165.

Bitto, I.I. and Gemade, M. 2001. Preliminary investigations on the effect of Pawpaw peel meal on growth, visceral organ and endocrine gland weights, testicular morphometry and the haematology of male rabbits. Global Journal of Pure and Applied $\quad$ Science 7(4): 611 -625 .

Bitto, I.I., Arubi, J.A. and Gumel, A.A. 2006 . Reproductive tract morphometry and some haematological characteristics of female rabbits fed pawpaw peel meal based diets. African Journal of Biological Research 9: 199-204. (http://www.ajbrui.com.).

Cheeke, P. R. 1986. Potentials of rabbit production in tropical and sub-tropical Agricultural systems. Journal of Agricultural Science 63: 1581-1586.

Egbunike, G.N. 1979. The effects of micro doses of aflatoxin $\mathrm{B}_{1}$ on sperm production rates, epididymal sperm abnormality and fertility in the rat. $\mathrm{Zbl}$. Vet. Med. 26: 66-72.

Fomunyam, AT., and Meffeja, F. 1987. Cassava by-products in rabbit and sheep diets. Pages 103-107 in Proceedings, Workshop on Utilization of Agricultural Byproducts as Livestock Feeds in Africa, edited by D.A. Little and A N. Said, African Research Network for Agricultural By-Products (ARNAB), September 1986, Blantyre, Malawi. ILCA, Addis Ababa, Ethiopia.

Gage, M.J.G. and Freckleton, R.P. 2003. Relative testis size and sperm morphometry across mammals: No evidence for an association between sperm competition and sperm length. Proc. of the Royal Society of London, B. 270: 625-632.

GenStat. 2005. GenStat User's Guide (Release 4.24). Lawes Agricultural Trust, Rothamsted Experimental Station, UK.

Kronfield, O.W. and Mediway, N.C. 1979. Blood chemistry. In: Textbook of Veterinary and Clinical Pathology. Williams and Williams Co., Baltimore. Pp.18- 96.

Morris, O. L., Smith, M. F., Parrish, W. R., William, J. D. and Wilbank, J. N. 1979. The effect of scrotal circumference, libido and semen quality on fertility of American Brahaman Santa Certruides bull”. Proc. of Animal Management of the Society for T h e r i o g e n o l o g y, Oklahoma, USA

Mitruka, B.M. and Rawnsley, H.M. 1977. Clinical Biochemical and Haematological reference value in normal experimental animals. Masson Publishing Co., New York. Pp. 102117.

Ogunlade, J.T., Ewuola, E.O. and Gbore, F.A. 2006. Testicular and epididymal sperm reserves of rabbits fed fumonisin contaminated diets. Int . Digital Organisation for Scientific Information. 1(1): 35-38.

Orji, B. I. 1985. Research on reproduction 
in small ruminants and their application in Nigerian production systems. Proc. Nat. Conf. Small Ruminant Production held at Zaria, Nigeria. Oct. 6-10

Oyawoye, E. O. and Ogunkunle, M. 1998. Physiological and biochemical effects of raw Jack beans on Broiler. Proc. Silver Anniversary Conf. Nig. Soc.Anim. Prod. h e $1 \mathrm{~d}$ a t Abeokuta, Nigeria (1998). Ed (s) O.O. Oduguwa, O.A. Fanimo and O.A. Osinowo. 23: 141-142.

Oyeyemi, M.O. and Okediran, B.S. 2007. Testicular parameters and sperm morphology of chinchilla rabbits fed with different planes of soymeal. International Journal of Morphology 25 (1):139-144.

Phuc, B.H.N., Ogle, B. and Lindberg, J.E. 2006. Nutritive value of cassava leaves for monogastric animals. Http://WWW.mellarn.org/prockk/phu c.htm.

Ravindran, V., Kornegav, E.T. and Rajaguru, A.S.B. 1987. Influence of processing methods and storage time on the cyanide potential of cassava leaf meal. Animal Science and Technology 17(4): 227-234.

Smith, O.B. 1988. A Review of ruminant responses to cassava based diet. Proc.
IITA/ILCA/UI workshop on potential Utilization of cassava as livestockfeed in Africa. IITA, Ibadan. Pp. 36-63.

TAC. (2009). Makurdi Weather Elements Records, Makurdi Metereological Station. Nigeria Air Force, Tactical Air Command, Makurdi, Nigeria.

Tewe, O.O., Maner, J.H. and Gomes, G. 1979. Influence of cyanogenic glucoside fraction of cassava on performance, thiocyanate concentration and rhodanese activities of rats during growth and production. Nigerian Journal of Animal Production 6(1\&2): 8- 14.

Tewe, O.O. 1992. Detoxification of cassava products and effects of residual toxins on consuming animals. In. Roots, tubers, plantains and bananas in animal feeding. FAO. Animal Production and Health Paper No. 95 Pp.81-98.

Torhemen, M. 2008. The effect of cassava peel meal on performance, blood chemistry and eproductive potentials of male rabbits. M.Sc. Thesis, De partment of Animal Prodiuction, University of Agriculture, Makurdi, Nigeria. Pp. 40-42.

Received: $15^{\text {th }}$ April, 2014

Accepted:20 ${ }^{\text {th }}$ February, 2015 